\title{
$\mathrm{PC}$ 그라우트의 재료분리 및 PC 빔 그라우팅 충전성에 관한 연구

\author{
이준기 ${ }^{1) *} \cdot$ 최준호 $^{1)} \cdot$ 윤정섭 $^{2)} \cdot$ 조인성 ${ }^{3)}$
} \\ 1)삼성물산(주) 건설부문 기술연구센터 ${ }^{2)}$ 삼성물산(주) 건설부문 토목사업본부 ${ }^{3)}$ (주)케어콘 기술연구소
}

\section{Study on Material Segregation of Grout and Filling Characteristic of Grouting for Post-Tensioned Concrete Beam}

\author{
Jun-Ki Lee, ${ }^{1) *}$ Joon-Ho Choi, ${ }^{1)}$ Jeong-Seob Yoon, ${ }^{2)}$ and In-Sung Cho ${ }^{3)}$ \\ ${ }^{1)}$ Research Institute of Construction Technology, Samsung C\&T Corp., 137-857, Korea \\ ${ }^{2)}$ Civil Division, Samsung C\&T Corp., Seoul 137-857, Korea \\ ${ }^{3)}$ Research Center, Chemicon Company Ltd., Chungcheonbuk-do 365-834, Korea
}

\begin{abstract}
This paper discusses a series of experiments including material improvement in order to ensure quality of grouting for the post-tensioned structure. In presstressed concrete, grouting refers to the construction procedure of filling empty space of duct enclosing the prestress tendons using cementitious material, To date, adequate quality control of the grouting has not been established in Korea because the relationship between the grouting and durability of post-tensioned structure is not well-recognized. The Korean standard does not consider the important material characteristic, wick effect, which is caused by tendons in the ducts, and furthermore current standard testing method does not quantify reasonable material segregation. As a result, the grout material, which satisfies the current material standards, may well exhibit excessive bleeding of water or shrinkage during construction. In this study, international codes and standards related to grouting were surveyed. The mix proportions of the constituents and novel admixtures were suggested to meet equivalently with these standards. Performance of this enhanced grout was compared with common domestic grouts using the international standard testing method. A series of mock-up specimens considering geometry of PC beam was constructed and grout flow pattern was observed as the grout was injected. It was observed that the grouting performance was highly influenced by material properties and filling characteristic can be varied depending on geometry of ducts.
\end{abstract}

Keywords : PC grout, durability, material separation, anti-bleeding, quality control

\section{1. 서 론}

$\mathrm{PC}$ (post-tensioned concrete) 그라우팅(grouting)이란 덕 트(duct)에 삽입된 강연선을 긴장한 후 이를 염화물과 같 은 외부의 유해한 물질로부터 보호하기 위하여 시멘트계 재료를 사용하여 덕트를 밀실하게 채우는 작업을 말한다. 포스트텐션 구조물은 인위적으로 압축력을 재하하여 발 생균열을 효율적으로 제어하기 때문에 $\mathrm{RC}$ (reinforce concrete) 구조물에 비하여 높은 내구성능을 가지고 있는 것으로 알려져 있다. 하지만, 최근 해외에서는 PC 구조 물의 부식피해 사례를 통해 포스트텐션 구조물의 사용수 명이 강연선의 부식방지와 직접적인 연관이 있음이 인지 되었다. ${ }^{1-3)}$ 이에 따라 PC 구조물의 내구성을 확보하기 위 하여 설계, 재료, 상세 및 시공방법에 많은 개선이 수행 되었으며, 특히 강연선을 보호하는 마지막 수단인 그라

*Corresponding author E-mail : jk0914.lee@samsung.com Received January 5, 2010, Revised February 17, 2010, Accepted February 19, 2010

(c) 2010 by Korea Concrete Institute
우트는 강연선의 부식을 방지할 수 있는 가장 효율적인 공정으로 인식되어 그 중요성이 강조되었다. 이는 그라 우트 공극의 발생을 방지하여 덕트를 완전 충전한다면 강연선을 외부 유해물질로부터 분리시킬 수 있어 부식이 발생하지 않기 때문이다. 이후 북미, 유럽, 일본 등에서 는 지속적인 연구가 시행되어 재료의 개선, 시험방법 개 발, 시방규정의 개정 및 공법의 최적화 등 적극적으로 그라우트 재료 및 시공 품질을 확보하려 노력하고 있다.

$\mathrm{RC}$ 구조물의 부식(corrosion)은 콘크리트 속 철근이 침 투한 염화물 등과 반응하여 발생하는 산화(oxidation)현 상을 의미한다. 이 경우 부식에 의해 구조적 결함이 생 기기전 $\mathrm{RC}$ 구조물에서는 녹물발생, 박리현상 등의 사용 성 문제가 발생하며 대부분 구조물의 안전성에 직접적인 영향을 미치치 않는다. 하지만 PC 구조물의 부식은 수 소원자가 철근분자에 침투하여 발생하는 응력부식(stress corrosion)의 형태인 수소취화(hydrogen embrittlement) 현 상을 말한다. 이 현상은 주로 고강도 강재에서 발생하며 피해가 누적될 경우 부식현상과 같은 녹물(rust)이나 균 열과 같은 시각적 경고없이 취성파괴되는 특징이 있다. 
따라서 PC 구조물에서 부식이 진행될 경우 손상에 대한 평가가 어려우나 손상이 누적될 경우 구조물의 안전성에 직접적인 영향을 미칠 수 있다. ${ }^{4}$

이 논문은 $\mathrm{PC}$ 그라우트의 충전성을 확보하기 위한 연 구를 기술하고 있다. 그라우트 관련 국내시방기준을 해 외시방기준과 비교한 후, 현재 사용되고 있는 그라우트 의 블리딩률을 ASTM 시험법을 사용하여 평가하여 보았 다. 해외기준을 만족시킬 수 있도록 그라우트재의 재료 구성비를 제안하고 혼화제를 개선하였으며 이를 연직관 시험법을 사용하여 일반재료와 비교평가하였다. PC 빔 의 덕트 목업실험체를 제작한 후 그라우트를 주입하여 충전유형을 관찰하고 재료의 충전성능을 평가하였다.

\section{2. 국내·외 시방기준 비교}

국내시방규정은 그라우트의 품질을 유동성, 블리딩률, 팽창률, 압축강도, 염화물 함유량의 5 개 시험항목으로 나 누고 있다. ${ }^{5,6)}$ 시방규정에 의하면 그라우트의 유동성은 시 공계획서에 따라 결정되며 블리딩 수의 발생을 $0 \%$ 로 제 한하고 있다. 또한, 그라우트의 팽창을 최대 $10 \%$ 까지 허 용하며 재료팽창에 따른 강도저하를 허용하고 있다. 따 라서 현재 일반적으로 팽창성 그라우트가 국내 포스트 텐션 그라우트 시공에 사용되고 있다. 그라우트 품질에 관한 국내시험항목 및 허용치가 Table 1에 요약되어 있 다. 이와 비교하여 해외기준은 보다 많은 품질시험항목 과 엄격한 품질기준을 제시하여 국내 그라우트 품질 기 준과 비교하여 높은 성능을 요구하고 있다. Table 2에는 미국의 Post-Tensioning Institute, ${ }^{7)}$ 일본토목학회의 콘크리 트 표준시방서, ${ }^{8)}$ 유럽의 British Standard, ${ }^{9}$ 품질관리 항 목, 그라우트 관련 표준시험법과 허용기준이 요약되어 있다.

국내시방규정과 해외시방규정의 가장 큰 차이는 재료
Table 2 Standard testing methods and rquirements by Korean standards

\begin{tabular}{c|c|c}
\hline Property & Method & Requirement \\
\hline \hline Fluidity & KS F 2432 & Specified by construction plan \\
\hline Bleeding & KS F 2433 & $0 \%$ \\
\hline $\begin{array}{c}\text { Volume } \\
\text { change }\end{array}$ & KS F 2433 & $\begin{array}{c}\text { Expansive type : 0 10\% } \\
\text { Non-expansive type : } \\
\text { no requirement }\end{array}$ \\
\hline $\begin{array}{c}\text { Compressive } \\
\text { strength }\end{array}$ & KS F 2426 & $\begin{array}{c}\text { Expansive type : 20 MPa@28 days } \\
\text { Non-expansive type : } \\
30 \mathrm{MPa} @ 28 \text { days }\end{array}$ \\
\hline $\begin{array}{c}\text { Chloride ion } \\
\text { contents }\end{array}$ & $\begin{array}{c}\text { KS F 4009 } \\
\text { appendix 1 }\end{array}$ & $\begin{array}{c}0.08 \% \text { by weight of cement } \\
\text { (or } 0.3 \mathrm{~kg} / \mathrm{m}^{3} \text { ) }\end{array}$ \\
\hline
\end{tabular}

분리에 대한 표준시험방법과 허용기준에 있다. 그라우트 의 재료분리는 물과 시멘트의 분리로 블리딩 수 발생량 과 비례하며, 재료수축과 밀접한 관계가 있다. 국내규정 은 블리딩 발생을 $0 \%$ 로 제한하여 재료분리를 방지하고 있지만 해외기준의 경우 그라우트 재료수축을 합리적으 로 측정할 수 있는 표준시험법을 각 국가 상황에 맞게 제정하였으며 블리딩률을 $0.0 \%$ 로 보다 엄격하게 제한하 고 있다. 이들 표준시험법은 $\mathrm{KS}$ 시험법과 두 가지의 차 이가 있는데, 첫째, 그라우트 시편에 강연선이 포함되어 있으며, 둘째, 중력에 의한 시멘트와 물의 분리를 고려 할 수 있다는 점이다. 또한 해외품질기준은 그라우트를 팽창성 및 비팽창성으로 나누지 않고 재료의 과다한 팽 창을 제한하고 있는데 이는 과다한 팽창은 그라우트의 투수성을 높일 수 있으며 수소가스 발생 등을 통한 팽 창은 강연선의 부식에 영향을 미칠 수 있기 때문이다. 일반적으로 그라우트의 팽창은 덕트 내의 그라우팅 충전 성을 높이는 것으로 인식되고 있으나, 이에 대한 연구나

Table 1 Summary of international standard testing methods and requirements

\begin{tabular}{|c|c|c|c|c|}
\hline \multicolumn{2}{|c|}{ Property } & PTI guide specification & \begin{tabular}{|c|} 
Standard specifications \\
for concrete structures (Japan)
\end{tabular} & $\begin{array}{c}\text { BS EN } 445 \& \\
\text { BS EN } 447\end{array}$ \\
\hline \multirow{4}{*}{$\begin{array}{l}\text { Fluidity/ } \\
\text { consistency }\end{array}$} & Testing method & ASTM C 939 & JSCE-F 531 & Cone method \\
\hline & Requirement & $\begin{array}{c}\text { 11 30 sec (non-thixotropic) } \\
5 \sim 11 \mathrm{sec} \text { (thixotropic) }\end{array}$ & $\begin{array}{c}\text { Specified by } \\
\text { construction plan }\end{array}$ & $25 \mathrm{sec}$ \\
\hline & Testing method & - & - & Grout spread \\
\hline & Requirement & - & - & $140 \mathrm{~mm}$ \\
\hline \multirow{4}{*}{ Bleeding } & Testing method & ASTM C 940 (modified) & JHS 420 & Wick induced test \\
\hline & Requirement & $0.0 \%$ & $\begin{array}{c}0.3 \% \\
0.0 \% @ 24 \mathrm{hr}\end{array}$ & 0.3\%@3 hrs \\
\hline & Testing method & Shupack pressure bleed test & - & Inclined tube test \\
\hline & Requirement & by standard chart & - & 0.3\%@3 hrs \\
\hline \multirow[b]{2}{*}{ Volume change } & Testing method & ASTM C 1090 & JHS 420 & Wick induced test \\
\hline & Requirement & $\begin{array}{c}0.0 \sim 0.1 \% @ 24 \text { hrs } \\
<0.2 \% @ 28 \text { days }\end{array}$ & $-0.5 \sim 0.5 \%$ & -1 5\%@24 hrs \\
\hline \multicolumn{2}{|c|}{ Other required property } & $\begin{array}{c}\text { Stregnth, } \mathrm{Cl}^{-} \text {content } \\
\text { setting time, permeability, } \\
\text { accelerated corrosion, wet density }\end{array}$ & Stregnth, $\mathrm{Cl}^{-}$content & $\begin{array}{l}\text { Stregnth, } \mathrm{Cl}^{-} \text {content, } \\
\text { setting time, seive, density }\end{array}$ \\
\hline
\end{tabular}


객관적인 자료는 없다는 것을 유의하여야 한다.

그라우트의 재료분리는 강연선의 유무에 따라 큰 영향 을 받는다. 강연선은 일곱개의 와이어가 나선형으로 꼬 여져 구성되는데 이 와이어사이의 틈을 통해 그라우트내 의 수분이 통과할 수 있는 길이 만들어져 그라우트 주 입 시 시멘트와 물의 재료분리가 촉진된다. 이는 심지효 과(wick effect)라고 불리는 현상으로 강연선이 없을 때 와 비교하여 많은 블리딩 수와 재료수축이 발생한다. 또 한 그라우트재는 주입되는 덕트의 기하형상이 높아질수 록 중력에 의해 물과 시멘트가 분리될 수 있는 가능성 이 높다. 따라서 낮은 형고를 가진 거더에 적용되는 그 라우트보다는 교각과 같이 높은 구조물에 적용되는 그라 우트에서 보다 많은 재료분리가 발생한다. 따라서 해외 품질평가방법은 모두 그라우트에 강연선을 배치하여 시 편을 제작하여 심지효과를 고려하고 있으며, 다양한 방 법으로 중력에 의한 효과를 모사하고 있다. 위의 그림 (Fig. 1)은 각 시방규정 중 대표적인 블리딩률 표준시험 방법을 나타낸 것이다. 국내표준시험법(KS F 2433)은 비 닐튜브에 약 $200 \mathrm{~mm}$ 높이의 그라우트를 채운 뒤 강연선 없이 블리딩률과 팽창률을 측정함으로써 실제발생 블리 딩 수를 과소측정하여 그라우팅 성능을 과다평가하게 되 는 단점이 있다. 이와 비교하여 JHS 419와 BS EN 445 표준시험법에 따르면 그라우트의 재료분리를 평가하기 위하여 $5 \mathrm{~m}$ 의 시편을 제작하여 12 개의 강연선을 삽입한 후 그라우트를 펌프를 통하여 하단부터 주입하는 시험법 을 사용하여 보다 실제 시공 시 발생할 수 있는 그라우 트의 재료분리량을 평가하고 있다. 이들 규정은 각 시방 서에 따라 항목별 표준시험법을 복수로 제정하였거나 별 도의 시험법을 사용하여 측정한다는 점을 유의하여야 한다.

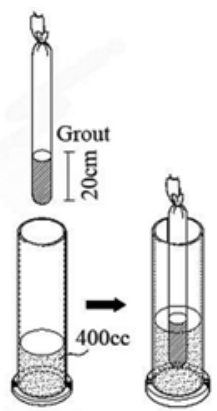

(a) KS F 2433

(c) JHS 420

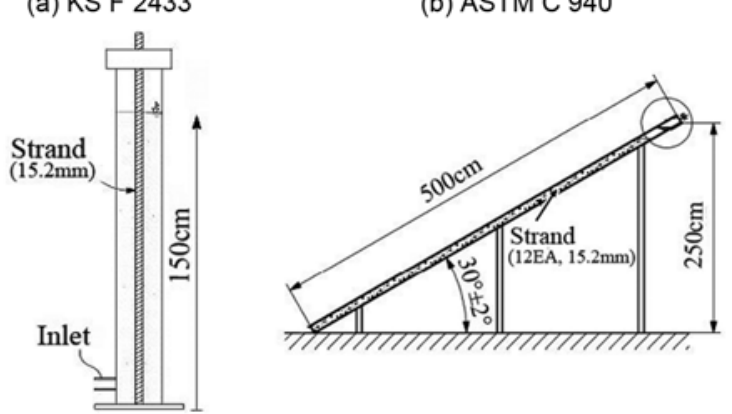

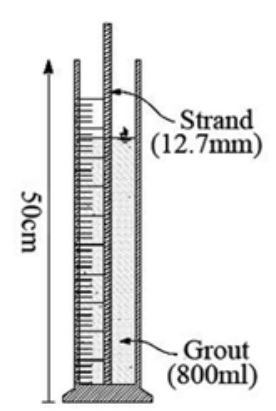

(b) ASTM C 940 (d) BS EN 445: Inclined tube and JHS 419

Fig. 1 Comparison of standard testing methods

이 논문은 그라우트의 재료분리 성능에 중점을 두어 그라우트의 압축강도와 염화물량에 관하여 언급하지 않 았다. 이는 그라우트의 개선을 위한 낮은 물-시멘트비 적 용은 그라우트 강도를 증진시키며, 그라우트는 배합 구 성이 단순하여 염화물 함유량이 재료품질에 큰 영향을 미치지 않을 것으로 예상되었기 때문이다.

\section{PC그라우트 품질평가}

\section{1 일반 그라우트 품질 평가}

$\mathrm{PC}$ 그라우트는 시멘트, 물, 혼화제로 구성된다. 현재 그라우트는 약 40 45\%의 물-시멘트비로 유동성 및 팽창 성이 있는 혼화제를 시멘트 질량의 $1 \%$ 비율로 배합하여 사용하는 것이 일반적이다. 이러한 그라우트의 성능을 평 가하기 위하여 국내시방기준을 만족하는 상용화된 제품 (시멘트와 그라우트 혼화제)을 사용하여 물-시멘트비에 따른 유동성과 블리딩률을 측정하였다. 국내시방서 ${ }^{11)}$ 는 물-시멘트비를 최대 $50 \%$ 로 규정하고 있다. 따라서 시료 의 35 50\% 사이 여섯구간으로 나누어 $\mathrm{KS} \mathrm{F} \mathrm{2432} 2^{12)}$ 방 법을 통하여 유동성를 3회 평가한 후 이를 평균하였고, 수정된 ASTM C 940 ${ }^{13)}$ 방법에 따라 블리딩률을 2회 측 정한 후 평균하였다(Fig. 2). KS F 2432 시험법은 그라 우트를 규정된 콘에 채운 후 자중에 의하여 그라우트가 흐르는 시간을 측정하는 시험법으로 측정된 시간이 낮을 수록 높은 유동성을 가지게 된다. 사용된 그라우트의 구 성비가 Table 3에 요약되어 있다.

그라우트의 성능은 물-시멘트비에 따라 민감한 변화를 보였다. 유동성은 물-시멘트비가 $50 \%$ 부터 $42 \%$ 까지는 완 만한 감소를 나타냈으나 물-시멘트비 $40 \%$ 이하부터 급 격히 재료의 점성이 증가하여 실험의 재현성이 어려울 정도로 유동성이 저감되었다. 유동성 규정은 현장조건을

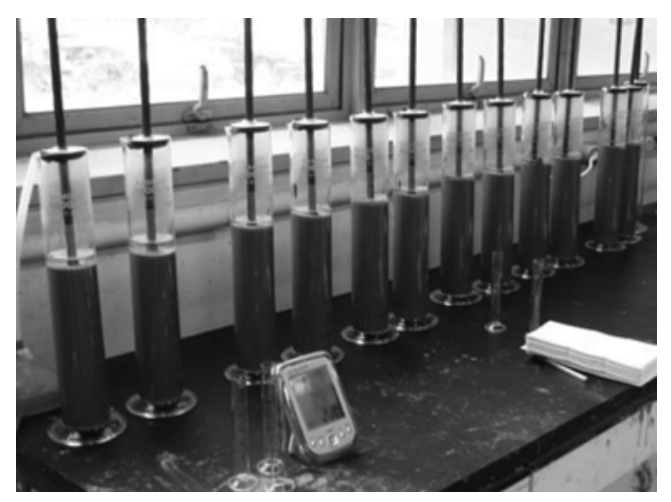

Fig. 2 Series of modified ASTM C940 test

Table 3 Grout mix proportion

\begin{tabular}{c|c|c|c|c|c|c}
\hline Sample & 1 & 2 & 3 & 4 & 5 & 6 \\
\hline \hline$w / c$ & 0.50 & 0.47 & 0.45 & 0.42 & 0.40 & 0.35 \\
\hline Admixture (\%)* $^{*}$ & 1 & 1 & 1 & 1 & 1 & 1 \\
\hline
\end{tabular}

$* \%$ by weight of cement 
고려하여 결정하도록 되어 있으며 일반적으로 7 14초로 규정된다. ${ }^{14)}$ 블리딩률의 경우 물-시멘트의 감소에 따라 블리딩률이 감소하는 경향을 나타내었으나, 물-시멘트비 를 $35 \%$ 까지 저감하여도 PTI 허용기준인 $0.0 \%$ 를 만족시 키지 못했다. 이는 현재 일반적으로 사용되는 그라우트 는 물-시멘트비를 $40 \%$ 대로 적용하여 작업성을 확보할 수 있지만, 이 경우 재료분리가 불가피하다는 것을 의미한 다. 또한 재료분리를 억제하기 위하여 물-시멘트비를 낮 출 경우 유동성 손실이 높아 작업성이 급격히 낮아짐을 나타낸다. 이는 충전성을 높이기 위해 보다 현 재료수준 보다 높은 재료분리 방지성능이 필요하며 동시에 유동성 을 확보하여야 함을 의미한다. 시험 결과는 Fig. 3에 요 약되어 있다.

\section{2 그라우트 개선 및 품질 평가}

재료분리 및 유동성에 관련된 해외기준을 만족하기 위 하여 그라우트의 성능을 다음과 같이 향상시켰다. 재료 분리를 방지하기 위하여 물-시멘트비를 $40 \%$ 대에서 $30 \%$ 로 감소시켰으며, 수축저감제를 사용하였다. 단위수량 감 소에 따른 유동성감소를 보상하기 위해 폴리카르본산계 고유동화제(고성능감수제)를 사용하였다. 점성증가, 흐름 성(flow)향상, 자기수평성(self-leveling)을 향상시키기 위 하여 3종의 혼화제를 더하여 액상화 혼화제를 제작하였 으며 이를 시멘트 질량의 $2.45 \%$ 로 배합하였다. 따라서 이 재료는 수축저감 효과는 가지고 있으나 팽창효과는 가지고 있지 않다. 적용된 그라우트의 배합비는 아래표 와 같다(Table 4). 아래의 배합은 경제성을 고려하여 수 립된 것으로 실리카품과 같은 결합제와 기타 혼화제를

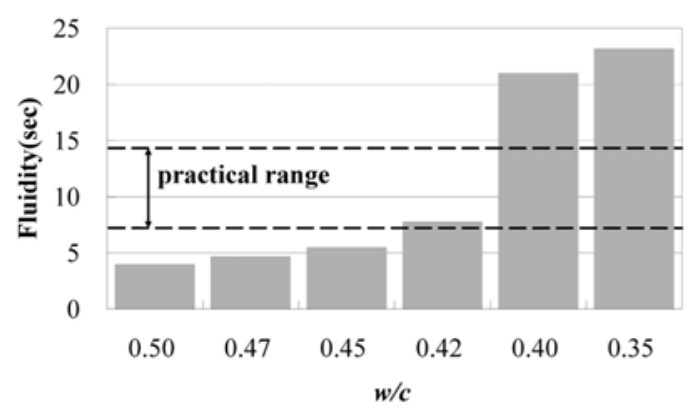

(a) Fluidity test (KS F 2432)

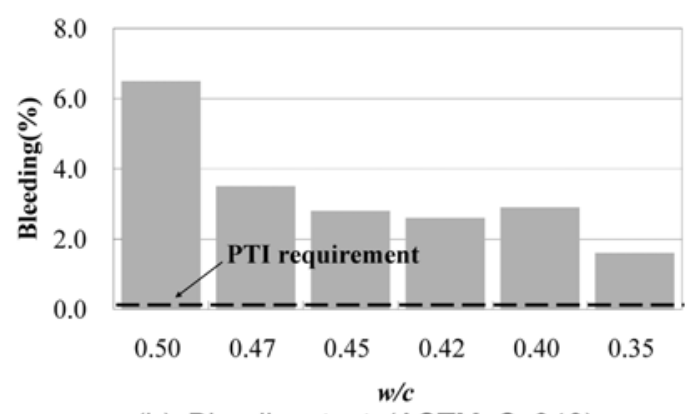

(b) Bleeding test (ASTM C 940)

Fig. 3 Evaluation of common grout with different w/c ratios
Table 4 Grout mix proportion

(\% by weight of cement)

\begin{tabular}{c|c|c|c|c|c}
\hline \multirow{2}{*}{ w/c } & \multirow{2}{*}{$\begin{array}{c}\text { Super- } \\
\text { plasticizer }\end{array}$} & \multirow{2}{*}{$\begin{array}{c}\text { Shrinkage- } \\
\text { reducing agent }\end{array}$} & \multicolumn{3}{|c}{ Additional admixture } \\
\cline { 4 - 6 } & redung & A1 & A2 & A3 \\
\hline \hline 0.3 & 1.2 & 0.8 & 0.1 & 0.05 & 0.3 \\
\hline
\end{tabular}

사용하여 다양한 방법으로 재료성능의 향상이 가능하다.

일반 그라우트와 개선된 그라우트의 성능을 연직관 시 험법(JHS 420) ${ }^{15)}$ 을 사용하여 평가하였다. 직경 $75 \mathrm{~mm}$ 의 높이 $2 \mathrm{~m}$ 투명 아크릴 파이프를 수직으로 배치한 후 7 개의 강연선을 중앙에 배치하였다. 아크릴 파이프의 하 단에 그라우트 주입구를 설치하여 이를 펌프에 연결하고 그라우트를 교반한 후 파이프에 주입하였다. 일반 그라 우트는 약 2분간 교반시간이 소요되었으나, 개선 그라우 트는 물-시멘트비가 낮아 약 5분간 교반시간이 소요되었 다. 주입은 총 높이 $2 \mathrm{~m}$ 중 그라우트가 $1.8 \mathrm{~m}$ 높이에 도 달했을 때 종료하였다. 시험규정은 그라우트 높이를 $1.5 \mathrm{~m}$ 높이로 규정하였으나, 이 시험에서는 재료분리를 증진시 키기 위하여 시료의 충전높이를 $300 \mathrm{~mm}$ 추가하였다. 주 입 이후 3 시간동안 발생하는 블리딩 수와 재료 수축량 을 측정하였다. 총 4 개의 시험체를 제작하였으며 아래 그림에 상세가 나타나 있다(Fig. 4). G1과 G2는 개선된 혼화제를 시멘트 질량비 $2.45 \%$ 로 배합한 시험체이며, G3 와 $\mathrm{G} 4$ 는 상용화된 2 개 혼화제를 시멘트 질량비 $1 \%$ 로 배 합한 시험체이다. G2에는 강연선을 삽입하지 않았다.

충전된 그라우트는 시간이 경화함에 따라 점차 재료분 리현상을 나타내었으나 사용된 그라우트 종류와 강연선 의 유무에 따라 그 정도에 많은 차이가 있었다. 특히 G1 과 $\mathrm{G} 2$ 는 사용재료의 차이에 의해 $\mathrm{G} 3$ 와 $\mathrm{G} 4$ 와 재료분리 정도의 차이를 나타내었다. G2의 경우 충전 3시간 이후 블리딩 수는 발생하지 않았으나 중력의 영향에 의해 $0.1 \%$ 의 미세한 수축을 나타냈다. 하지만 $\mathrm{G} 1$ 에서는 블리딩이 $0.3 \%$ 발생하였으며, $0.6 \%$ 의 수축률이 발생하였다. 이는 강연선에 의한 심지효과(wick effect)에 의하여 그라우트 재료분리량이 증가되었음을 의미한다. 이와 비교하여 $\mathrm{G} 3$ 와 $\mathrm{G} 4$ 는 많은량의 블리딩 수와 재료수축량이 크게 나타

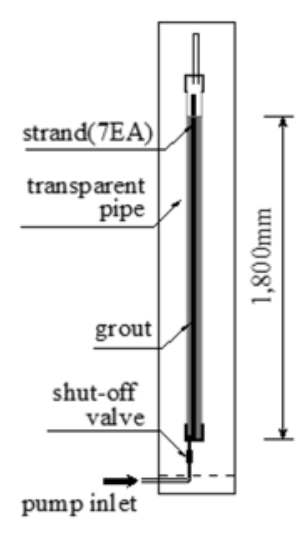

(a) Geometry

\begin{tabular}{c|c|c|c}
\hline Specimen & $w / c$ & Strands & Grout \\
\hline \hline G1 & 0.3 & $\circ$ & enhanced \\
\hline G2 & 0.3 & $\times$ & enhanced \\
\hline G3 & 0.42 & $\circ$ & common \\
\hline G4 & 0.42 & $\circ$ & common \\
\hline
\end{tabular}

(b) details
Fig. 4 Bleed and volume change test 
났다. 이는 높은 물-시멘트비, 강연선의 심지효과 및 그 라우트 자중에 의하여 재료분리 현상이 증진되었기 때문 이다. 또한 $\mathrm{G} 3$ 와 $\mathrm{G} 4$ 에 사용된 그라우트재는 팽창성능을 가지고 있었으나 실제 실험이 재료가 팽창하는 효과는 크게 나타나지 않았다. 주입 후 3시간 후 발생된 블리딩 률과 수축률이 Fig. 5와 Table 5에 나타나 있다. 시간경과 에 따른 블리딩 수 발생과 수축량은 Fig. 6에 나타나 있 다. 그라우트 시공 시 초기 충전높이 이상의 블리딩 수는 벤트(vent)를 통하여 덕트 외부로 유출될 수 있으나, 초기 충전높이 이하의 블리딩 수는 재충전되지 않는다면 후에

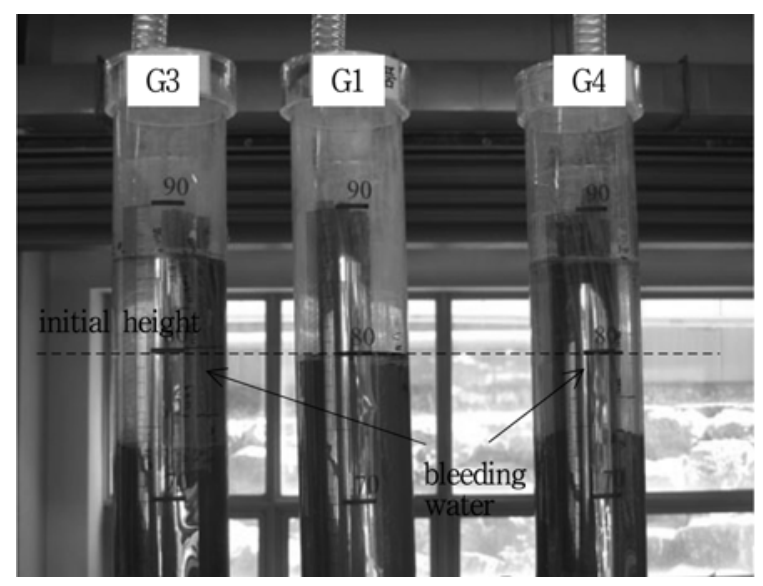

Fig. 5 Material segregation after 3 hours

Table 5 Final bleeding and volume change (@3hr) (unit:\%)

\begin{tabular}{c|c|c|c|c}
\hline & G1 & G2 & G3 & G4 \\
\hline \hline Bleeding & 0.3 & 0.0 & 7.2 & 6.5 \\
\hline Volume change & -0.6 & -0.1 & -3.7 & -3.0 \\
\hline
\end{tabular}
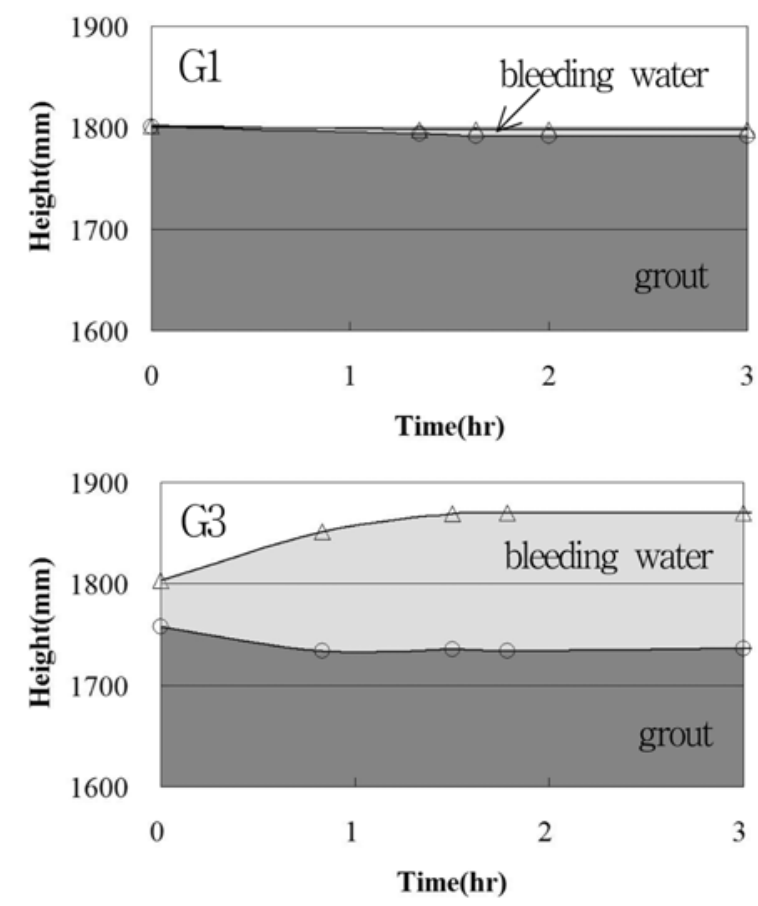

Fig. 6 Material segregation until 3 hours
증발하여 그라우트 공극이 된다. 이 경우 배치된 덕트의 최상단부에서 그라우트 공극이 발생할 가능성이 있다.

일본 콘크리트시방서에 의하면 3시간 후 블리딩률은 $0.3 \%, 24$ 시간 후 블리딩률은 $0.0 \%$ 이하로 허용하고 있 으며 수축량을 $-0.5 \sim 0.5 \%$ 로 제한하고있다. 이는 그라우 트의 팽창성능을 최대 $0.5 \%$ 까지 허용하여 블리딩률을 낮 추려는 것으로 보이며 팽창률을 3시간과 24시간으로 나 누어 그라우트의 팽창이 주입초기에 집중되는 것을 제한 하였다. 개선된 그라우트재는 3시간 후 블리딩 허용기준 을 만족하였으나 팽창성능이 없어 24시간 후 블리딩 허 용기준을 초과하였다. 또한 3 시간 후 수축량은 $-0.6 \%$ 로 허용 기준을 $0.1 \%$ 초과하였다. 하지만, 초과치가 크지 않 으며 위의 실험이 규정된 그라우트 충전높이 보다 약 $20 \%$ 높게 주입되어 자중의 효과와 심지효과가 증가하였 다는 것을 고려하여 볼 때, 개선된 그라우트는 일본 콘 크리트 시방규정의 허용기준에 준하는 성능을 나타낸 것 으로 보인다.

그라우트의 유동성은 물-시멘트비와 유동화제의 특성 에 따라 크게 영향을 받았다. 유동성은 KS F 2432 시험 법에 따른 콘시험방법(cone test method)을 사용하여 경 과시간별로 재교반 후 반복 측정하였다. 따라서 이 시험 법은 덕트를 통해 흐르는 그라우트의 유동성을 나타낸다. 물-시멘트가 $42 \%$ 인 일반 그라우트는 교반 직후 높은 유 동성(낮은 컨시스턴시)을 나타내었으나 시간이 경과함에 따라 유동성이 점차 감소하는 경향이 나타났다. 반면 낮 은 물-시멘트비를 가진 개선된 그라우트는 교반 직후 낮 은 유동성(높은 컨시스턴시)를 나타냈으나 시간이 경과 함에 따라 점차 유동성이 회복되었다. 이는 폴리카르본 산계 고유동화제의 특성에 따라 그라우트의 유동성이 오 랜 시간 지속되었기 때문이다. 또한 측정된 유동성은 펌 프 주입성능과 비례하지 않았는데, 주입 시 개선 그라우 트는 낮은 유동성을 나타냈음에도 불구하고 일반 그라우 트와 비교하여 낮은 압력으로 펌핑주입이 가능하였기 때 문이다. 이는 개선된 그라우트는 높은 점성을 지니고 있 으나 흐름성(flow)이 높기 때문이다. 따라서 그라우트의 특성이 변할 경우 콘시험만으로는 유동성을 적절히 나타 내지 못할 것으로 보이며 British Standard와 같이 콘시험 법과 흐름성을 고려할 수 있는 그라우트 퍼짐시험(grout spread test)을 병행하여 사용하는 것이 바람직 할 것으로 보인다. 아래그림에는 시간경과에 따른 컨시스턴시의 변 화가 나타나 있다(Fig. 7).

\section{4. 목업시험을 통한 그라우팅 충전평가}

그라우트 시공 시 덕트 내부 그라우트 충전성을 조사 하기 위하여 덕트의 기하형상이 단순한 포스트텐션 보를 대상으로 실스케일 목업시험을 2회 실시하였다(Fig. 8). 1 차 목업실험은 높이 $1.7 \mathrm{~m}$ 의 길이 $20 \mathrm{~m}$ 를 가진 시험체 를 3 개 제작하여 수행하였다. 일반그라우트와 성능이 향 상된 그라우트를 사용하여 주입하였으며, 반투명호스에 


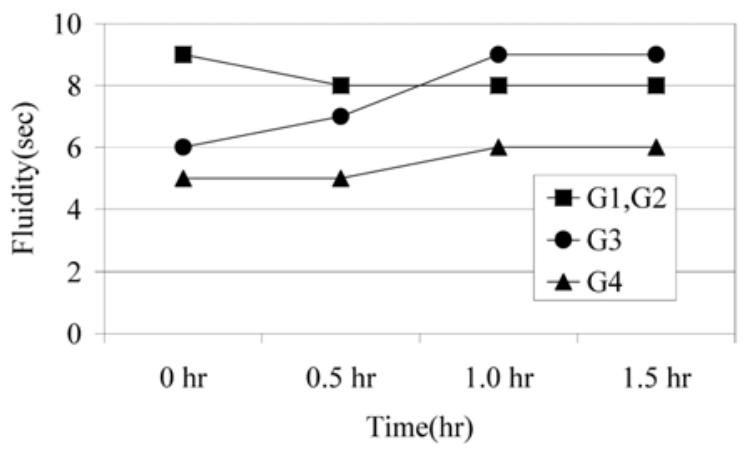

Fig. 7 Time-dependent consistency variation

1st Mock-up using transparent tube

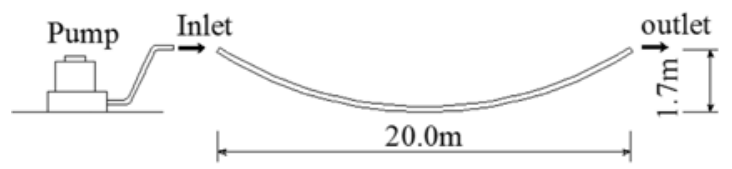

2nd Mock-up using metal sheath

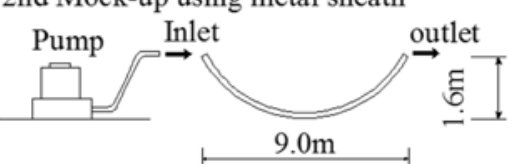

(a) Geometry of specimens

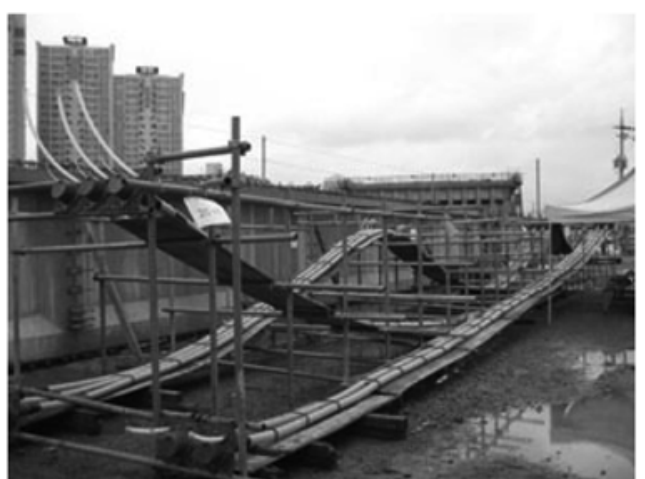

(b) 1st mock-up test(semi-transparent tube)

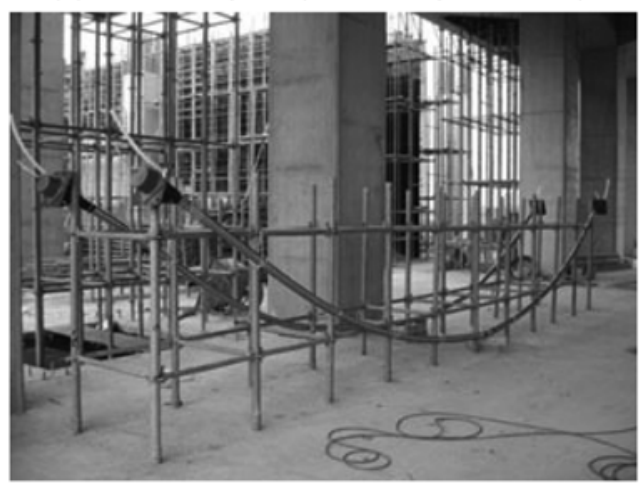

(c) 2nd mock-up test (metal sheath)

Fig. 8 A series of mock-up test in large scale

앵커부를 연결하여 실험체를 제작하여 그라우트 주입 시 충전패턴을 확인하였다. 덕트내에서는 강연선을 7 개 배 치하였으며, 양단부에 앵커 플레이트를 고정한 후 앵커 헤드를 사용하여 정착하였다. 그라우트는 플런저(plunger) 타입의 펌프를 사용하여 주입하였으며, 경화 후 튜브 및 앵커부를 절단하여 충전정도를 확인하였다. 1차 목업시
험 시 3 개의 기하형상을 가진 총 8 개의 시험체를 시험 하였으나, 이 논문에서는 그 중 $\mathrm{PC}$ 빔의 덕트형상을 가 진 3 개의 시험체만을 언급하였다. 2 차 목업시험은 높이 $1.6 \mathrm{~m}$ 의 길이 $9 \mathrm{~m}$ 를 가진 실험체를 2 개 제작하여 실시하 였으며, 덕트내에는 8 개의 강연선을 배치하여 성능이 향 상된 그라우트를 주입하였다.

그라우트 주입 시 사용 그라우트에 따라 흐름유형(flow pattern)에 많은 차이가 나타났다. 개선된 그라우트는 일 반 그라우트에 비해 점성이 커서 컨시스턴시가 크나 고 유동화제의 사용으로 플로우가 크며 자체-수평성질(selfleveling)을 가지고 있다는 차이가 있다. 일반 그라우트는 펌프주입 시 덕트의 주입구부터 충전되어 서서히 덕트를 따라 유출부로 충전이 진행되어지는 경향을 보였다(Fig 9). 이 경우, 주입구에 선행적으로 충전된 그라우트는 후 속 그라우트 의해 계속 유출구 쪽으로 밀려 움직이게 된 다. 따라서 덕트의 길이가 길어질수록 높은 압력이 요구 될 것으로 보인다. 이에 반해 개선 그라우트는 프로우가 높아 주입 시 덕트의 하단부를 먼저 충전한 후 양단부 쪽으로 충전되는 형상을 보여주었으며 그라우트 주입부 의 압력이 높아 주입부 방향 덕트가 유출부 방향 덕트 에 비해 먼저 충전되었다. 이 경우 덕트의 길이가 증가 하더라도 일반 그라우트에 비해 낮은 압력으로 그라우트 주입이 가능할 수 있다.

주입된 그라우트는 덕트내에서 재료가 분리될 경우 블 리딩 수가 발생하며 재료가 수축된다. 블리딩 수의 발생 은 추후 수분의 증발에 의하여 그라우트 공극을 생성시 키며 재료수축 역시 그라우트 공극을 증대시키는 요소이 다. 재료분리현상은 덕트의 최상부, 즉 $\mathrm{PC}$ 보의 경우 앵 커헤드부에서 발생하였다. 또한 덕트 중간부에서 발생한 블리딩 수는 앵커부까지 이르지 못하고 갇힌 상태로 증 발하여 그라우트 경화 후 물길모양의 공극이 발생하였다.

그라우트 충전 시 덕트 내부에서 발생된 공기가 적절 히 외부로 배출되지 못한다면 갇힌 공기는 에어포켓(airpocket)을 생성하여 그라우트 경화 후 공극이 생성될 수 있다. 위에서 나타난 것과 같이 플로우가 높은 그라우트 는 충전이 하단부터 진행되는 경우 주입구 덕트 상단으 로 갇힌 공기가 발생할 수 있다. 일반적으로 사용되는 앵커플레이트의 주입부에는 그라우트 주입구 외의 공기

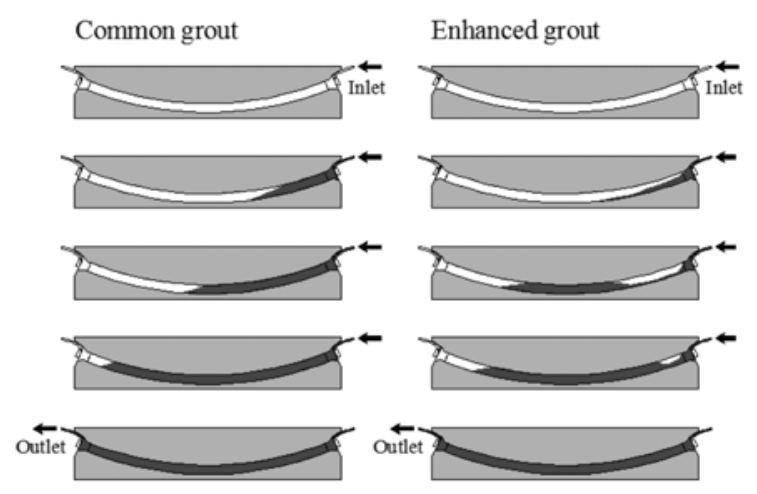

Fig. 9 Flow pattern depending on grout type 
가 통할 수 있는 경로가 없으며 주입구를 통해 펌핑된 그라우트가 주입되기 때문에 공기의 유출이 외부로 적절 히 이루어지지 않을 수 있다. 또한 앵커헤드에 시멘트페 이스트를 사용하여 그라우트 마개로 사용하는 경우 이를 통한 공기의 유출과 수밀성을 보장하기 어렵다. 이를 고 려하여 이 목업에서는 앵커플레이트 부에 앵커헤드를 감 쌀 수 있는 그라우트 캡을 적용하였으며 그라우트 캡에 공기유출을 위한 에어벤트(air-vent)를 Fig. 10과 같이 설 치하였다.

2 차 목업시험은 1 차 목업시험과 비교하여 시공 시 사 용되는 금속쉬스관을 사용하였으며 회전작용(rotary action) 을 통해 그라우트를 주입하는 모노펌프(moineau pump) 를 사용하여 그라우트를 주입하였다. 금속쉬스관은 투명 호스에 비하여 점성이 낮아 그라우트 주입이 용이하였으 며 플런저펌프를 모노펌프로 대치하여 그라우트의 압력 변화 없이 그라우트의 연속적인 주입이 가능했다. 그라 우트 주입 시 반복적인 플런저의 활동을 통하여 그라우 트를 주입하는 펌프의 사용보다 압력의 변화가 없는 모 노펌프 타입을 사용하는 것이 충전성을 높일 수 있을 것 으로 보이며 이 경우 저압주입이 가능한 그라우트를 사 용하는 것이 유리하다.

그라우트 경화 후 금속쉬스관을 절단하여 덕트부의 충 전성을 평가하였고 그라우트 캡을 제거하여 앵커부의 충 전성을 평가하였다. 덕트부의 전체단면에서 그라우트가 밀실하게 충전되었음을 알 수 있었다(Fig. 11(a)). 단면의 상단에 미세한 방울모양의 공극이 발생하였으나, 이는 쉬 스관 리브상단에 미세한 공기가 갇혀 발생한 것으로 보 이며, 강연선을 보호하는 그라우트의 역할에는 영향을 미 치치 않을 것으로 판단되었다. 그라우트캡을 제거하였을 때 앵커부는 그라우트에 의해 충전되어 있었다(Fig. 11(b)). 그라우트는 에어벤트 높이까지 충전되었는데, 이는 에어 벤트를 통하여 그라우트가 유출되어 에어벤트 위로 일부 공기가 유출되지 못했기 때문이다. 이는 에어벤트의 위 치를 그라우트 캡의 상단부로 이동함으로써 쉽게 보완할 수 있을 것으로 보인다. 이 목업시험은 그라우트의 완전 충전은 그라우트 재료특성, 덕트의 형상, 그라우트 장비 및 상세를 적절히 고려하여야만 가능함을 나타낸다.

\section{5. 결 론}

이 연구는 포스트텐션 구조물의 그라우트 시공 시 높
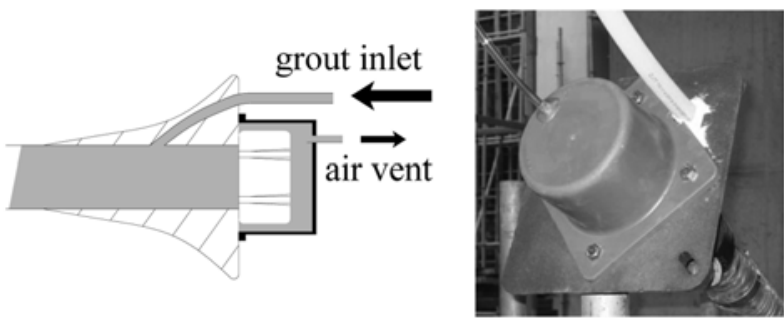

Fig. 10 Installation of air vent

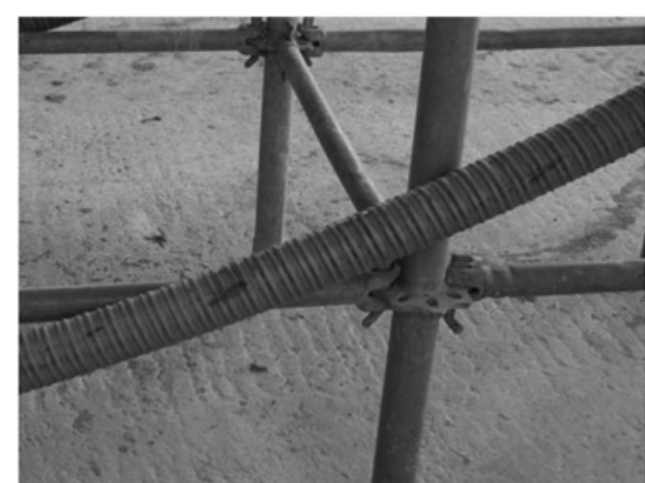

(a) Free length

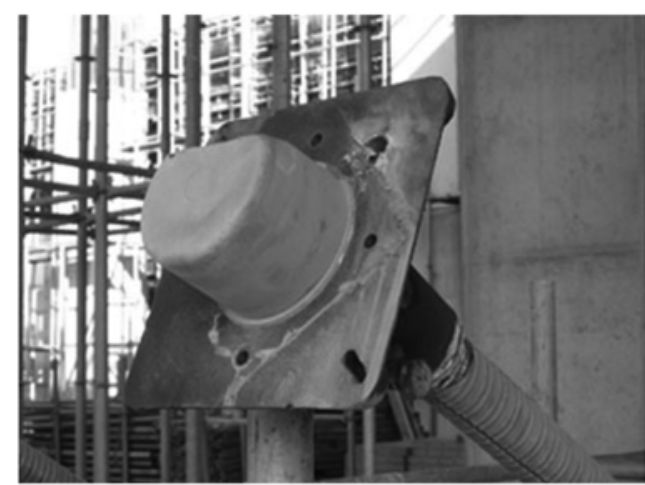

(b) Anchorage

Fig. 11 Verification of complete grouting

은 충전성을 확보하기 위하여 그라우트 품질 및 시공법 을 개선하는데 목적이 있다. 이 논문의 결과는 다음과 같이 요약할 수 있다.

1) 해외 규정은 포스트-텐션 구조물의 내구성 강화를 위하여 그라우트 품질기준을 강화하였으나, 아직 국 내규정은 이를 반영하지 못하고 있다. 또한 표준시 험법은 심지효과(wick effect)를 고려하지 못함으로 인해 그라우트 재료분리를 과소평가하여 국내기준 을 만족하는 $\mathrm{PC}$ 그라우트에서도 시공 시 블리딩 수 및 재료수축이 발생할 수 있다.

2) 그라우트 시공 시 덕트 내부의 충전성을 향상시키 기 위하여 그라우트의 재료분리 방지와 유동성이 확보되어야 한다. 이에따라 물-시멘트를 저감하고 혼화제를 개선하여 그라우트의 성능을 향상하였다. 이를 연직관 시험법을 사용하여 일반 그라우트와 비교 평가하여 재료 성능을 검증하였다.

3) $\mathrm{PC}$ 보 덕트를 모사한 목업시험체에 그라우트를 주입 하여 그라우트 충전성을 평가하였다. 그라우트는 재 료특성에 따라 상이한 흐름유형(flow pattern)을 나 타냈다. 그라우트의 재료분리가 발생할 경우 공극 이 발생할 수 있음을 알 수 있었다.

4) 목업시험을 실시하여 그라우트 시공의 충전성능을 평가하였다. 그라우트 품질성능 향상, 앵커부 상세 개선과 모노펌프의 사용을 통하여 $\mathrm{PC}$ 보 그라우트 시공의 충전성능을 확보할 수 있었다.

5) 그라우트 시공 시 높은 충전성을 얻기 위해서는 재 료특성, 시공법, 장비 및 상세에 이해가 필요하다. 
이 논문에서는 $\mathrm{PC}$ 보 그라우트 시공의 성능을 높이 기 위한 과정을 기술하였으나, 다양한 그라우트 재 료 및 덕트의 기하학적 형상 따른 영향 등의 추가 적인 연구를 통하여 여러 포스트텐션드(post-tensioned) 구조물의 그라우트 충전성능을 향상시킬 수 있을 것이다.

\section{감사의 글}

이 연구를 위해 많은 도움을 주신 삼성물산(주) 건설 부문 수인선 4공구 현장 관계자 여러분께 감사드립니다.

\section{참고문헌}

1. Woodward, R., "Durability of Post-Tensioned Tendons on Road Bridges in the UK," Durability of Post-Tensioning Tendons, fib-IABSE Technical Report Bulletin, No. 15, 2001.

2. Corven Engineering Inc., "Mid-Bay Bridge Post-Tensioning Evaluation," Final Report, to Florida Department of Transportation District 3, Tallahassee, Florida, 2001.

3. Poston, R. W., Frank, K. H., and West, J. S., "Enduring Strength," ASCE Civil Engineering, 2003.

4. ACI Committee 222.2R-01, "Corrosion of Prestressing Steels," ACI Manual of Concrete of Practice, Committee
Report 222.2R-01.

5. 한국콘크리트학회, 콘크리트표준시방서, 한국콘크리트학 회, 2009, $319 \mathrm{pp}$.

6. 국토해양부, 도로공사표준시방서, 국토해양부, 2009, pp. 6 178.

7. PTI Grouting Specifications Committee, Specification for Grouting of Post-Tensioned Structures, PTI Guide Specification, Post-Tensioning Institute, 2003.

8. 土木學會，コンクリ一ト標準示方書(施工編), 土木學會, 2007, $400 \mathrm{pp}$.

9. BS EN 445, Grout for Prestressing Tendons-Test Methods, British Standards Institution, 2007.

10. BS EN 447, Grout for Prestressing Tendons-Basic Requirements, British Standards Institution, 2007.

11. 대한토목학회, 토목공사 표준일반시방서, 대한토목학회, 2005, 277 pp.

12. KS F 2432, 주입 모르타르의 컨시스턴시 시험방법, 한 국표준협회, 2004.

13. ASTM C 940-98a, Standard Test Method for Expansion and Bleeding of Freshly Mixed Grouts for Preplaced-Aggregate Concrete in the Laboratory, ASTM international, 2003.

14. 대한토목학회, 철도공사전문시방서(토목편), 대한토목 학회, 2004, 290 pp.

15. JHS 420, PCグラウトのブリ一ディング率及び体積変化率 試験方法(鉛直管方法)，コンクリ一/卜標準示方書(規準編), 2004.

요 약 이 논문에서는 포스트텐션 구조물에 적용되는 그라우팅 품질확보를 위한 재료개선 및 실험과정을 기술하였 다. 그라우팅이란 강연선이 삽입된 덕트를 시멘트물질로 채우는 공정이다. 국내에서는 아직 그라우팅의 품질과 포스트 텐션 구조물의 내구성에 대한 관계가 인식되지 않아 적절한 품질관리에 어려움이 있다. 국내표준시험법은 강연선에 의 한 심지효과(wick effect)를 고려하지 않기 때문에 시공 시 발생할 수 있는 재료분리량을 평가하기 어렵다. 따라서 현 품 질기준을 만족하는 그라우트를 사용하더라도, 시공 시 과다한 불리딩 수나 재료수축이 발생할 수 있다. 이 연구에서는 그라우트에 관련된 해외기준과 표준시험법을 조사하여 국내기준 및 표준시험법과 비교한 후 해외기준에 준하는 성능을 나타낼 수 있는 그라우트 구성성분비 및 혼화제를 제시하여 보았다. 개선된 그라우트의 성능을 해외표준시험법에 따라 일반적으로 적용되고 있는 그라우트재와 비교하였으며 $\mathrm{PC}$ 빔의 덕트형상을 고려한 목업시험을 통하여 흐름유형(flow pattern) 및 충전성능을 관찰하였다. 이 실험을 통하여 그라우팅의 성능은 재료특성에 의하여 높은 영향을 받으며 적용 대상의 기하학적 형상에 따라 상이한 충전특성을 가진다는 것 알 수 있었다.

핵심용어 : PC 그라우트, 내구성, 재료분리, 블리딩 방지, 품질관리 